\title{
An asymmetrical approach to understanding configurations of customer loyalty in the airline industry
}

\begin{abstract}
This study employs fuzzy set qualitative comparative analysis (fsQCA) to examine asymmetrical relationships among service attributes, relationship quality, and customer loyalty in the airline industry. The study incorporates customers' demographics and psychological variables to model customer loyalty. Customer loyalty is operationalised as behavioural and attitudinal dimensions in order to capture customers' actual behaviours and behavioural intentions. Symmetrical testing is also used to compare findings with those from fsQCA application. The study provides various causal recipes or configurations for predicting relationship quality and customer loyalty. The comparison between symmetrical and asymmetrical findings presents deeper and more insightful information. These findings provide useful guidelines and references for the relevant researchers and practitioners. The study also contributes to the literature by utilising symmetrical and asymmetrical tools to advance understanding of antecedent conditions of relationship quality and customer loyalty.
\end{abstract}

Keywords: customer characteristics; service quality; customer loyalty; asymmetrical testing; fsQCA

Acknowledge: the authors are grateful for Professor Arch Woodside who provided invaluable guidance in the course of this research. 


\section{RESEARCH BACKGROUND}

Customer loyalty has been extensively discussed in the relevant literature. Achieving customer loyalty is a key strategy to gaining competitive advantage for firms. Over decades loyalty research has been centred on identifying and analysing antecedents of customer loyalty and examining structural relationships among these predictors. Factors that precede customer loyalty include service quality and customer satisfaction or relationship quality (Caruana, 2002; Hallowell, 1996; Orel and Kara, 2014; Rauyruen and Miller, 2007;

Storbacka and Strandvik, 1994). Researchers (e.g. Hesket et al., 1994) propose that delivering premium service is important to satisfy customers. Happy customers stay loyal to the business. Customer loyalty accounts largely for business profitability.

Nevertheless, some researchers (e.g. Kale and Klugsberger, 2007; Prentice, 2013; 2014; Zeithaml, Berry and Parasuraman, 1996) argue that customer satisfaction is not a necessary condition of loyalty. In many cases satisfied customers do not return to the business (Bowen and Shoemaker, 1998; Griffin and Herres, 2002; Reichheld, Markey and Hopton, 2000). On the other hand, service quality does not always lead to customer satisfaction and loyalty. Service quality is generally conceptualized as a multidimensional construct, consisting of several dimensions that are classified on the basis of customers' perception of various service encounters. Firms endeavour to ensure delivering quality service over each encounter to generate positive perceptions and assessment of the firm's service quality and to achieve customer satisfaction. Despite such effort, research (e.g. Prentice, 2014) shows that some dimensions of service quality have negative impact on customers' favourable behavioural intentions. These studies reveal asymmetrical complex relationships among service quality, customer satisfaction and loyalty.

However, the symmetrical testing of service quality-customer satisfaction-loyalty link appears to be dominant in the literature. This testing predominantly uses regression analyses 
and structural equation modelling to generate symmetrical relationships between these constructs. This approach explicitly assume high or low values of independent variable $\mathrm{X}(\mathrm{X}$ can be a single variable or a group of variables) associate with high or low values of a dependent variable (Y) (see Woodside, 2013; Woodside, Prentice and Larsen, 2015). The symmetrical assumption is rather simplistic. Ragin (2008) contends that $\mathrm{X}$ and $\mathrm{Y}$ are rarely symmetrically related in real life contexts, and that asymmetrical relationships are often present. This contention is consistent with the complexity theory proposed by Byrne (2005). The theory indicates that both high and low scores of $X$, depending on the configuration, can lead to high outcomes of $Y$. In some cases, the same outcome is produced by different or contradictory paths.

Woodside (2013) points out various flaws in the prevalent symmetrical testing in business research. Drawing on the complexity theory, he asserts that a research paradigm shift is emerging by adopting asymmetrical testing of the XY relationships. This testing employs fuzzy-set qualitative comparative analysis (hereafter fsQCA) to examine asymmetrical relationships between $\mathrm{X}$ and $\mathrm{Y}$. FsQCA uses algorithms to examine outcome conditions and "rests on both a quantitative and qualitative approach to data analysis and theory in that the method is able to generalize across cases while still being able to explain complexity at the case level" (Woodside, Prentice, \& Larsen, 2015, p. 66). Originally developed for sociology and political science, FsQCA has been gaining attention in business research (e.g. Fiss 2007; Greckamer et al., 2008).

In addition to investigating complex relationships between $\mathrm{X}$ and $\mathrm{Y}$, fcQCA uses Boolean algebra to examine configuration of causal conditions for the outcome. Outcomes of interest rarely result from a single causal factor; causal factors rarely operate in isolation; and, the same causal factor may have different — even opposing — effects depending on the context (Greckhamer et al. 2008). Such principles imply “equifinality”. The concept of equifinality 
indicates that the same outcome can be achieved through different configurations of causal factors (Ragin 2000). While the configurations of factors pertaining to a phenomenon can potentially be numerous, equifinal configurations effectively explain the phenomenon and typically reduce to a few coherent patterns of attributes. FsQCA is a set-membership analytical technique appropriate for complex configuration analyses (Ragin 2000).

Consistent with above discussion, the current study employs fsQCA to examine complex relationships among service provisions and customer responses (e.g. customer satisfaction, loyalty) in the airline industry. Competition in this industry is intensifying. Gaining customer patronage and loyalty is key to achieve competitive advantage. This study draws on the complexity theory and uses asymmetrical testing to identify the factors that may attract passengers' positive response to respective airlines.

Prior studies have revealed that servicescape or intrinsic cues are important stimuli leading to customer satisfaction or loyalty (e.g., Bitner, 1992; Wakefield and Blodgett, 1994; Tombs and McColl-Kennedy, 2003; Kim and Moon, 2009; Loureiro et al., 2013). In the context of air transportation researchers have pointed out the importance of customer experience (Zomerdijk and Voss, 2009) and particularly the effects of in-flight attributes or the servicescape of the plane (e.g. ambience, sitting, design of the aircraft) on air travellers' decision (Han, 2013) and loyalty (Han and Hwang, 2014). However, findings from prior research are primarily drawn on individual service attributes and generated through symmetric approaches. In this research, we deploy fsQCA and propose a holistic approach to investigating configurations of attributes associated with airlines as well as with the passengers in explaining customers' attitudes and behavioural outcomes.

The antecedent conditions examined in the study are services related to the airlines including in/out aircraft attributes. Customers' demographic-psychological variables are also included in the analyses. The rationale for this inclusion is discussed next. The outcome 
variables in this study are focused on passengers' relationship quality with the airline and their loyalty. Relationship quality has been considered as a set of intangible values in the exchange between a customer and a seller or a provider (e.g., Levitt, 1986; Crosby et al., 1990). Although there is no consensus on which dimensions make up relationship quality, three constructs have been regarded as the core dimensions: satisfaction, trust and commitment (e.g., De Wulf et al., 2001; Athanasopoulou, 2009; Tsaur et al., 2014). These dimensions are important in explaining customer loyalty (e.g., Akamavi et al., 2015; Garbarino and Johnson, 1999; Loureiro and Miranda, 2008).

Specifically this study investigates how the antecedent conditions (flight attributes) are combined to predict the outcomes (relationship quality and loyalty). The purpose of configuration analysis is to discover those few equifinal configurations. The relationship between airline carriers and passengers is a complex and multidimensional phenomenon, in which the configuration of the in-flight attributes is more important than the individual attribute. There should be an appropriate fit between the configuration and passengers' demographic-psychological variables. This investigation uses Boolean algebra rules to identify which of the attribute combinations, if any, act as sufficient or necessary conditions for the outcomes (relationship quality and behaviour intentions) (Fiss, 2007). The same attributes, depending on their configuration with other attributes, can also foster or inhibit passengers' relationship quality and loyalty. The purpose of configuration analysis is to discover those few equifinal configurations.

The present study contributes to the literature by demonstrating asymmetrical ways of thinking about relationships for complex antecedent conditions and outcomes-which allows for a more nuanced understanding of the underlying configurations on how customers' combine service facet evaluations when assessing airlines. In doing so, the study includes contrarian case analysis (CCA). CCA includes nearly all data sets whereby an indicator 
(independent variable) associates with an outcome (condition or dependent variable) in a manner that counters to the reported principal symmetric relationship.

\section{HYPOTHESES}

\section{Drivers and Outcomes of the Airline Service Providers}

Inflight attributes are generally believed to affect passengers' perception of service quality and satisfaction with the airline (see Han, Sean and Kim, 2014). These attributes primarily refer to the aircraft's tangible elements including ambient conditions (e.g. air quality, temperature, odour, noise) and other servicescape components (e.g. layout, sittings, equipment and amenities) (Han 2013; Han and Hwang, 2014). However, a plethora of research (e.g. Bettencourt and Gwinner, 1996; Sirianni, Bitner, Brown and Mandel, 2013; Prentice 2013; 2014; Singh, 2000) has stressed the role of service employees in shaping customer attitudes and behaviors. The service provided by employees on the aircraft, namely flight attendants, is a key to estimating the airline's perceived service quality (An \& Noh, 2009). Researchers (Ryu and Jang, 2007; Loureiro, 2015) highlight importance of considering social elements that mainly involve the interactions between service employees and passengers. However, prior research on flight attendants is primarily focused on their employee-related outcomes (e.g. turnover, health issues) (e.g. Chen, 2006; Rafnsson, Tulinius, Jonasson and Hrafnkelsson, 2001; Remonlds, Cone, Layefsky, Goldberg and Hurley, 2002). This research includes the service performed by flight attendants in the analyses of relationship quality and loyalty.

In addition to in-flight attributes, outside-flight services, for instance, availability of flights and online service that facilitate passengers' travel are also important to perception of the airline's service quality. Very little research has attended to these aspects to understand customers' responses. Today, travelling by air is one of the most popular means for national and international travellers. Flight frequency and availability provide convenience for 
frequent flyers. Naturally air travellers would prefer airlines that provide more flights on daily or weekly bases. The internet service also eases travellers' busy lives. Travellers today tend to book and arrange their air travels online. The services that facilitates online purchase also affect travellers' preference and loyalty towards the airline. The foregoing discussion leads to the following hypothesis.

H1: Both in/out-flight attributes form complex antecedent conditions for passenger relationship quality with the airlines.

$\mathrm{H} 2$ : Both in/out-flight attributes form complex antecedent conditions for passenger loyalty with the airlines

Most research approaches to service quality and customer behaviours from service providers' perspective. Service production takes place simultaneously which indicates that the production process involves service providers and customers (Lovelock and Gummesson, 2004). Both parties play a role in producing a successful service transaction. Customers' proactive engagement in this process may enhance their positive experience and satisfaction as well as improving value creation (Jaakkola and Alexsander, 2014; Sashi, 2012).

Customers' demographic characteristics also relate to their attitudes and behaviours (Bishop and Hathcote, 1994; Cooil, Keiningham, Aksoy and Hsu, 2007). Keaveney and Parthasarathy (2001) indicate that customers' demographic background can be used to distinguish loyal customers from switchers.

Aside from their demographic characteristics, customers' psychological status such as mindfulness also plays a role in their purchasing and consumption behaviors (Barber and Deale, 2014). Moscardo (2009) indicates that mindfulness is a precursor to perceive authenticity in tourism experience, personal meaning, and appreciation of the place and the environment. Mindfulness can be referred to as representing a state of mind expressed by actively processing (engagement) available information (e.g., brochures) within the 
surrounding environment and as a type of disengagement from information in one's surroundings (see Frauman and Norman, 2004). This construct is generally operationalized into adventurousness, engagement, novelty seeking and producing. This discussion informs the following hypotheses:

H3: Passengers' demographics and mindfulness form unique configuratoins of antecedent conditions of quality blended associations with the airlines.

H4: Passengers' demographics and mindfulness form copmplex antecedent conditions indicating their loyalty with the airlines.

Relationship quality has been widely regarded as antecedents of customer loyalty (e.g. Rauyruen and Miller, 2007; Sirdeshmuch and Singh, 2002; Storbacka, Strandvik and Gronroos, 1994). This concept generally involves three dimensions: customer satisfaction, trust and commitment. Each of these dimensions often functions alone or collaboratively and plays an important role in customer loyalty (Hallowell, 1996; Sirdeshmukh, Singh, and Sabol, 2002; Zins, 2001). Prior research has primarily examined symmetrical relationships between relationship quality dimensions and customer loyalty. Some studies focus on the impact of each individual dimension, for instance, customer satisfaction, on customer responses. Other researchers (e.g. Griffin and Herres, 2002; Prentice, 2013; 2014) argue that a single dimension per se does not necessarily generate positive outcomes (i.e. customer loyalty). Consistent with this view, the study proposes the following:

H5: Configurations of relationship quality constructs (customer satisfaction, commitment and trust) associate with high or low level of customer loyalty. 
The conceptual model of this study is depicted below.

\title{
Insert Figure 1 here
}

\begin{abstract}
METHOD

\section{Sample and data collection procedure}

The study was undertaken at Lisbon airport in Portugal. The airport agreed to help with this survey. Data were collected from passengers who have air travel experiences through Europe in both low cost carriers and prestigious airlines. The latter refer to legacy or flag airlines (hereafter flag airlines). The research assistants approached prospective respondents at the waiting areas near the departure gates and invited them to participate the survey. A small gift (e.g. coffee or food vouchers from the restaurant outlets at the airport) was offered for voluntary participation.
\end{abstract}

The original version of the questionnaire was written in English. It was translated to Portuguese and other main European languages to capture all passengers. The non-English versions of questionnaire were back translated to English to ensure consistency. Before launching the formal survey a pilot test was conducted with passengers who understood English and their native languages to assure that the sentences were well written and understood. As a result, a few minor changes were made with their suggestions.

A total of 350 questionnaires were distributed, and 304 usable responses (after excluding those with missing values, inconsistent responses or extreme multivariate outliers) were generated. The outliers were deleted using the graphic method, with a residual scatter plot in the range of \pm 3 standard deviation (Hair, Black, Babin and Anderson, 2010). Of the participants, 51 percent of the participants were male. 36 percent were in the age group between 21 and 30, 29 percent in the age group between 31 and 40. These two groups accounted for the majority of the sample. The group under 20 years old take 12.5 percent, 8.5 percent between 41 to 50 years old, 8.2 percent between 51 and 60, and 5.6 percent over 60 . 
Concerning the nationality, the majority of the participants were Portuguese (80\%) and as for other nationalities, the top 3 are German (5.6\%), French (4.3\%) and Spanish (3.3\%).

\section{Measurement}

The questionnaire was developed using scales from previous studies. All items were assessed using a 5-point Likert-type scale. The items that were used to assess inflight attributes including air quality, temperature, odour and noise were adapted from Bitner (1992), d'Astous (2000), Han and Ryu (2009), Kim and Moon (2009), Ryu and Jang (2007). Other servicescape elements (i.e. space/function, layout, equipment and amenities) were assessed by items adapting from Bitner (1992), d'Astous (2000), Han and Ryu (2009), Ryu and Jang (2007). The items measuring the service provided by crew/flight attendants was taken from Hightower et al. (2002) and Bitner (1992). The scale measuring customer commitment was adapted from Johnson et al.'s (2006) study. Overall satisfaction and trust were adapted from Oliver and Swan (1989) and Loureiro and Miranda (2008). Finally, the items measuring customer loyalty including behavioural and attitudinal dimensions were taken from Maxham and Netemeyer (2002). The reliabilities and correlations among the study variables are present in Table 1 below.

\section{Insert Table 1 here}

\section{Common method bias}

Several steps were taken to avoid/minimise common method bias. First, the items and questions in the questionnaire were kept simple and concise. Unfamiliar terms and complex syntax were avoided to minimise ambiguity. Second, the items measuring the same construct were spread through the questionnaire to ensure consistent response. Negative items corresponding to the positive ones were also used to check consistency. No significant discrepancy was detected. 


\section{DATA ANALYSIS}

FsQCA (Fiss 2007; Ragin 2000) was used to test the hypotheses. FsQCA is a settheoretic method that empirically examines the relationships between all possible combinations of its predictors and the outcome variables (satisfaction, trust, commitment and customer loyalty) (Longest and Vaisey 2008). The application of fsQCA (www.fs/QCA) involves four sequential tasks (Fiss 2011): (i) definition of the property space (also called truth table), (ii) development of set-membership measures, evaluation of consistency in set relations, and (iii) logical reduction.

The definition of the property space consists of all possible configurations of drivers of an outcome. Our study employs important drivers identified by the tourism and marketing literature. Accordingly, the property space consists of all combinations of binary states, that is, presence or absence, of the in/out-flight attributes (payment method, available flights, online service, crew, sitting, facilities, ambience), and demographic-psychological variables (age, gender, profession, mindfulness), and the type of airline carrier.

The next step in applying fsQCA is the assessment of the subset relationships: evaluating which configurations of attributes or recipes can act as sufficient conditions for relationship quality and customer loyalty. Recipe refers to "a specific combination of causally relevant ingredients linked to an outcome" (Ragin, 2008, p.9). Assessment of the degree of membership for each case in a given causal recipe is determined by "the degree of membership in the intersection of the fuzzy-set causal conditions that comprise the recipe" (Ragin, 2008, p. 9). This requires cross-case comparison of memberships between the causal sets (configurations of attributes, demographic-psychological variables), and the outcome set. The type of airlines (i.e. low cost versus flag airlines) are also included in the analysis. A consistent subset relation with fuzzy measures emerges when membership scores in a given 
causal set of attributes are consistently less than or equal to the membership scores in the outcome set.

Consistency refers to "how closely a perfect subset relation is approximated" and measures "the degree to which the cases sharing a given combination of conditions in displaying the outcome in question" (Ragin, 2008. P.45). Consistency is the degree to which the cases share a simple or complex condition in displaying the outcome in question (consistency is analogous to a correlation in statistical analysis) (Wu et al., 2014). Consistency is similar to the significance test which determines whether a proposed connection between a causal recipe and outcome is warranted. For a configuration to be considered sufficient, its consistency measure should statistically exceed a minimum threshold, so that a "few" inconsistent cases are allowed because of random error (Fiss 2007).

The final step in applying fsQCA is to prune the sufficient configurations by eliminating redundant elements. For each final sufficient configuration, a coverage measure is then calculated. Coverage assesses the degree to which a simple and complex causal condition accounts for instances of an outcome condition (coverage is analogous to a $\mathrm{R}^{2}$ in statistical analysis) (Wu et al., 2014). Coverage is indicative of the strength or importance of the connection between causal recipes and outcomes. It assesses empirical relevance or importance and measures "the degree to which a cause or causal combination 'accounts for' instances of an outcome" (Ragin, 2008, p. 45). A small coverage may be caused by existence of several paths to the same outcome.

While consistency is a measure of the significance of a subset relationship, coverage is a measure of its relevance and reflects the share of consistent memberships as a proportion of total memberships in the outcome set. On the other hand, coverage enables the assessment of the empirical importance of sufficient configurations. In fsQCA a consistency index above 
0.85 with a coverage index of 0.40 indicates high membership scores in the outcome condition for nearly all high scores in the antecedent statement and a substantial share of the cases fitting an asymmetric sufficiency distribution (Ragin, 2008). FsQCA is based on the concept of set membership (Boolean algebra) and our variables are not naturally dichotomous (presence/absence of attributes), so we generate membership measures using a fuzzy-set calibration approach, which allows membership scores to reflect the varying degrees to which different cases belong to a set, ranging from 1 (full membership in the set) to 0 (full nonmembership in the set), with intermediate membership levels in between (Ragin 2000).

Ragin (2008) emphasizes that fuzzy sets, unlike conventional variables, must be calibrated. Fuzzy-set calibration makes use of external information on the degree to which cases satisfy membership criteria and not inductively derived determination (e.g., using sample means). Criteria need to be set for three breakpoints in fuzzy-set calibration with endpoints of 0.00 for full non-membership to 1.00 for full membership. 0.05 is the threshold point of full non-membership; 0.50 is set for the crossover point of maximum membership ambiguity; and 0.95 for the threshold of full membership. Determination of the three breakpoints permits calibration of all original values into membership values using a direct method and an indirect method (Ragin, 2008). The original values in 5-point Likert scale can be calibrated so that $1=0.05 ; 2=0.25 ; 3=0.50 ; 4=0.75 ; 5=0.95$. Table 2 shows the calibrations for all conditions in this study.

\section{Insert Table 2 here \\ FINDINGS}

The findings follow the conceptual model in Figure 1. We examined unique antecedent conditions of all relationship quality constructs (i.e. satisfaction, commitment and trust) and customer loyalty, as well as the relationships between relationship quality and customer loyalty. Truth tables are used to exhibit the connection and strength between causal 
recipes and outcomes. Truth table is the key tool for analysing causal complexity using fsQCA, showing structured and focused comparisons. The table list "the logically possible combinations of casual conditions and the empirical outcome associated with each configuration" (see Ragin, 2008, p.23). In this examination, we report the results of demopsychographic conditions first, then the in/out-flight attributes conditions as the latter involves symmetrical testing as a comparison to those from performing fsQCA (asymmetrical testing).

\section{Findings for antecedent conditions of customer satisfaction}

Tables A1 and A2 report the findings of configuration of customer satisfaction. X indicates negation of membership; $\mathrm{O}$ is indicative of full membership. Blank represents absence from the configuration. Under the column of airline, $\mathrm{O}$ represents flag airlines; $\mathrm{X}$ is indicative of low cost airlines. Table 3 shows six complex recipes predicting customer satisfaction. The results reveal that engagement, professionals, elder and females are most frequently sighted recipes predicting customer satisfaction. The nature of the airlines (i.e. low cost) appears to have little influence on customer satisfaction. In the case of in/out-flight attributes, eight complex recipes are shown in predicting customer satisfaction. Among all selected ingredients, payment for extra service such as seat reservation, flight availability, inflight facilities and ambience appear in most of the eight models. Model 3 shows that all ingredients but online service in the case of low cost airlines are important predicting customer satisfaction.

\section{Refer to Tables A1 and A2}

Following this results, we performed regression analysis to examine which attribute/s make/s unique significant contribution to customer satisfaction. Before determining whether separating analysis on the basis of airlines, T-test was conducted to check if passengers' perception of these attributes between low cost and flag airlines are significantly different. 
Table 3 shows absence of significant difference. Based on this result, regression analyses were not separately for the airlines. Table 4 shows that among seven attributes, only online service and sitting have insignificant beta values with $\mathrm{p}>.05$. This result is only consistent with that in Model 3 appear in Table A2. The findings in asymmetrical testing show that customer satisfaction has much more complex antecedent conditions.

\section{Insert Table 3 here}

\section{Findings for antecedent condition of customer commitment}

The findings include only two recipes in the case of demo-psychographics predict customer commitment. Table A3 shows that novelty in both models does not predict customer commitment. Interestingly Model 2 shows that young males with less highly paid job tend to commit to flag airlines. Table A4 shows the results of in/out-flight attributes configuration for predicting customer commitment. Four recipes appear. No/low payment for extra service is important to attract passengers' commitment to the airlines as shown in Models 1 and 3. To some, online services explains very little in their commitment (see Models 3 and 4). However, in the regression analysis, results show that only ambience, sitting, online service and flight availability make unique contribution to customer commitment. Inflight facilities, crew and extra payment do not. However, the former two appear in all models explaining customer commitment in asymmetrical testing as shown in Table A3.

\section{Refer to Tables A3 and A4}

\section{Findings for antecedent condition of trust}

Eight recipes of demo-psychographics appear to predict trust. Among these recipes, older professional males with high level of novelty production and engagement tend to have high levels of trust on flag airlines as shown in Table A5. In the case of flight attributes, crew, sitting, inflight facilities and ambience are the most active ingredients in explaining 
passenger trust on the airlines (see Table A6). In the regression testing, crew and facilities show no significant effects on the outcome variable in Table 4.

\section{Refer to Tables A5 and A6}

The results presented above confirm Hypothesis 1 that both in/out-flight attributes form complex antecedent conditions for passenger relationship quality with the airlines. In particular, the following causal recipes have substantial coverage over .40 for relationship quality.

1. $\sim$ Payment $\bullet$ Availability $\bullet \sim$ Online service $\bullet$ Crew $\bullet$ Sitting $\bullet$ Facilities $\bullet$ Ambience $\leq$ Customer satisfaction

(Raw coverage: .42; Consistency: .95)

2. $\sim$ Payment $\bullet$ Flight availability $\bullet$ Crew $\bullet$ Sitting $\bullet$ Facilities $\bullet$ Ambience $\leq$ Commitment

(Raw coverage: .42; Consistency: .91)

3. Flight availability $\bullet$ Online service $\bullet$ Crew $\bullet$ Sitting $\bullet$ Facilities $\bullet$ Ambience $\leq$ Commitment

(Raw coverage: .42; Consistency: .93)

4. $\sim$ Payment $\bullet$ Flight availability $\bullet \sim$ Online service $\bullet$ Crew $\bullet$ Sitting $\bullet$ Facilities $\bullet$ Ambience $\leq$ Trust

(Raw coverage: .46; Consistency: .97)

Note: The tilde $(\sim)$ represents the negation (full nonmembership) in the condition and the mid-level $\operatorname{dot}(\bullet)$ represents the "logical and" in fuzzy sets.

\section{Findings for antecedent condition of customer behavioural loyalty}

Seven demo-psychographic configurations appear to predict passenger behavioural loyalty. Results show that those who often choose low cost airlines are scored high in mindfulness. These individuals are generally adventurous, highly engaged and full of novelty. Interestingly some senior professionals with high wages also favour low cost airlines as shown in Models 1-4 (see Table A7). These are probably retirees based on their age arrange. In the case of flight attributes, nine models (Table A8) explain passenger behavioural loyalty. 
Those who favour low cost airlines tend to rate all attributes highly (see Models 1 and 2); whereas those fly flag airlines do not mind much about inflight attributes. Perhaps these airlines are assumed to have better facilities. Convenience plays an important role in their behavioural loyalty. Indeed, regression analysis shows that inflight facilities and sitting have nonsignificant beta values. Crew and ambience (inflight attributes) do have significant effects on passenger behaviour loyalty. However, these attributes are not rated high in Models 6, 8 and 8 for crew, in Models 6 and 8 for ambience.

\section{Refer to Tables A7 and 8}

\section{Findings for antecedent condition of attitudinal loyalty}

There are 11 models of demo-psychographics explaining passenger attitudinal loyalty. Table A9 shows that older professionals with high scores of engagement tend to patronage low cost airlines. In terms of flight attributes, it appears all factors (five out of 10 recipes) are important in passengers' intention to fly again with the airlines. The airlines seem to be irrelevant to their decision. This finding is fairly consistent with that from regression analysis, in which inflight facilities and payment for extra services have nonsignificant beta values. However, some models in Table 10 contrast to this result. On the basis of these findings, H24 receive support.

\section{Refer to Tables A9 and 10}

In summary, the following models demonstrate substantial coverage in explaining the loyalty outcomes.

1. Payment $\bullet \sim$ Flight availability $\bullet$ Online service $\bullet$ Crew $\bullet$ Sitting $\bullet$ Facilities Ambience $\leq$ Behavioural Loyalty

(Raw coverage: .37; Consistency: .98)

2. $\sim$ Novelty seeking $\bullet$ Novel producing $\bullet$ Engagement $\bullet$ Professional $\bullet$ Senior $\bullet$ Female $\bullet$ Low cost airlines $\leq$ Behavioural Loyalty

(Raw coverage: .41; Consistency: .93) 
Note: The tilde ( ) represents the negation (full nonmembership) in the condition and the mid-level dot $(\bullet)$ represents the "logical and" in fuzzy sets.

\section{Findings for the relationship between relationship quality and customer loyalty}

Results from performing fsQCA show that customer satisfaction is irrelevant to passenger behavioural loyalty although it predicts attitudinal loyalty in one model (see Tables A11 and 12). However trust is key to customer loyalty to the airlines (either low cost or prestigious ones). Interestingly, low commitment still predicts behavioural and attitudinal loyalty. Regression analysis shows that all relationship quality constructs have significant effects on passenger behavioural loyalty (see Table 4). Nevertheless only satisfaction relates to attitudinal loyalty. Hence, H5 is partially supported.

\section{Insert Table 4 here}

\section{Refer to Tables A11 and 12}

The models that have outstanding coverages are shown below:

1. Trust $\bullet$ Commitment $\leq$ Behavioural loyalty

(Raw coverage: .70; Consistency: .94)

2. Trust $\bullet$ Low cost airlines $\leq$ Attitudinal loyalty

(Raw coverage: .38; Consistency: .87)

Note: The mid-level dot $(\bullet)$ represents the "logical and" in fuzzy sets.

\section{DISCUSSION AND CONCLUSIONS}

The current study employs an asymmetrical testing tool fsQCA to examine the relationships among flight attributes, customers' demo-psychographics, relationship quality, and customer loyalty in the airline industry. This testing presents all possible antecedent configurations (recipes) for achieving the outcomes. In particularly, the analyses include contrarian cases (those shown as $\mathrm{X}$ in the tables) and examine the role they play in customer attitudes and behaviours. The findings point out that complexity theory and fsQCA are useful tools for understand that simple antecedent conditions relate to an outcome of interest 
positively, negatively, or not at all. Each of these three relationships occur depends on the observed complex antecedent conditions in which the simple antecedent conditions occur. Positive outcome (relationship quality or customer loyalty) is not the mirror opposite of negative outcome. This study highlight the importance of co-aligning the multiple attributes of air-flight attributes and individual demographic-psychological variables, also including the type of airline carrier, for increasing relationship quality and customer loyalty. Unlike traditional symmetrical testing by using multiple regression or structural equation modelling, this study provides more insights into relationship quality and customer loyalty research. Symmetrical analysis is also included in the discussion. The detail findings are discussed as follows.

\section{Antecedent conditions for relationship quality}

Six configurations of demographic-psychological variables predict customer satisfaction consistently; eight of them explain trust; however only two models accounts for customer commitment. The findings indicate that individuals who are rated high in engagement, mostly elder professionals tend to have higher level of relationship quality with airlines of their choices. Some who are less adventurous, lack of novelty seeking and producing seem to be more satisfied with flag airlines. Nevertheless, some contrarian cases do appear. That is, individuals with similar demo-psychographic background are more satisfied with low cost airlines. In general, mindfulness plays a significant role in predicting relationship quality with airlines. The majority of those rated in low in mindfulness have higher relationship quality with flag airlines. This finding is plausible. Given aviation disasters in recent years, passengers generally would prefer "safe" airlines which have higher safety ratings despite the higher ticketing price except those who are more adventurous and like seeking or producing novelty. 
In the case of flight attributes, eight recipes explain customer satisfaction, four for customer commitment and eight for trust. The findings show that both in/out-flight attributes account for customer satisfaction, especially inflight attributes. Payment for extra services including fee for seat reservation and check in luggage influences customer satisfaction. In most cases ( 5 out of 8 models) passengers prefer not to be charged. Interestingly the majority (contrarian cases) do not fancy online services such as online check-in. These days most airlines use online services including booking and check-in which are supposed to facilitate passengers travelling and provide more convenience. The study finding contrasts to this assumption. Nevertheless, the regression analysis shows that online service is not significantly related to customer satisfaction because this symmetrical testing do not include contrarian cases. Should this technique be applied alone in this study, the non-significant finding would be misleading.

Achieving customer commitment to the airlines is primarily attributed to inflight services, i.e. friendly crew, comfortable sitting, modern facilities and pleasant ambience. Flight availability also predicts commitment (appear in 3 models). Free service for seat reservation and luggage check-in also explains passenger commitment to the airlines. Some passengers do wish less online services for low cost airlines. However, in symmetrical testing, flight facilities, crew service and payment for extra service show non-significant effects on passenger commitment. Without taking contrarian cases into account, the symmetrical and non-symmetrical findings are consistent. The latter provides more insightful information.

Similarly, inflight services co-exist with customer trust. Out-flight services have rather complex figurations for explaining customer trust. The results show that those who choose low cost airlines are more willing to pay for extra services (seat reservation and luggage check-in). They seem to be used to the idea of cheap flights coming with fee for 
other services. Among all eight recipes for customer trust, ambience appears in all configurations. Perhaps the elements in ambience (air quality, odour, noise, temperature etc.) indicate the quality of the airlines. However, again, the symmetrical testing shows that facilities, crew, online service and payment for extra service do not account for customer trust. Flight availability has a substantial effect on customer trust. In asymmetrical analysis, 4 out of 7 models show that this factor is not important in predicting trust.

\section{Antecedent conditions of customer loyalty}

Customer loyalty is operationalised into behavioural and attitudinal dimensions. Seven configurations of demographic-psychological variables appear to explain behavioural loyalty. The findings show that those who are rated high in adventurousness fly frequently with low cost airlines. Novelty seeking and engagement also accounts for patronizing these airlines. The old and young groups, regardless of gender, tend to choose low cost airlines. These groups are probably at low income range. Indeed, young group co-exist with lowlypaid jobs. However, the senior group appear to have professional background. Perhaps these are retirees. These findings indicate that airlines should look into these demo-psychological information to understand customer relationship with the airlines.

In the case of flight attributes, both in and out flight services account for customer behavioural loyalty. The findings indicate that those who fly with low cost airlines rate high in inflight services; whereas flag airline passengers are indifferent towards these services, but are mindful of flight availability and payment for extra services. These passengers probably assume that high cost airlines should have premium in-and-out-flight services. Regression analysis shows that only inflight facilities and sitting do not contribute to customer behavioural loyalty.

Eleven configurations of demographic-psychological variables explain customer attitudinal loyalty. In this scenario, engagement plays a significant role in customers' 
intention to fly again with the airlines they are used to. Other dimensions of mindfulness are rated in either low or high. Most retirees and young passengers with lowly paid jobs intend to fly again with the low cost airlines. However, some very young passengers indicate they will be stick to flag airlines. Perhaps this group mostly consist of students who are financially supported by their parents.

Similar to the case of behavioural loyalty, both in-out-flight attributes account for customer attitudinal loyalty. A few cases appear to be indifferent towards these services in their intentions to fly again with their chosen airlines. Regression analysis shows that inflight facilities and payment for extra services have non-significant effects on attitudinal loyalty. This analysis provides very limited information on customers' intention to fly with the airlines. In asymmetrical testing, facilities in 5 out of 10 models account for attitudinal loyalty, and payment for extra service in 6 out of 7 models predicts the outcome.

In examining the conditions between relationship quality and customer loyalty, interestingly customer satisfaction does not predict behavioural loyalty in asymmetrical testing, regardless the type of air carriers. In the case of attitudinal loyalty, some who are rated low in satisfaction still express intention to fly again with their chosen airlines (either low cost or flag ones). Indeed, prior research has shown that customer satisfaction does not necessarily predict customer loyalty. In some cases, satisfied customers do not return (Prentice, 2013; 2014). Among three relationship quality constructs, trust is the most prominent factor in explaining customer loyalty. Either low or high commitment predicts loyalty. Whilst in symmetrical testing, all three factors significantly contribute to customer behavioural loyalty. However, only commitment predicts attitudinal loyalty. Such discrepancy shows merits of asymmetrical analysis by providing more insights. 


\section{IMPLICATIONS}

The current study employs fsQCA to examine asymmetrical relationships among attributes associated with airlines, relationship quality and customer loyalty. The study contributes to the literature by providing a fresh look into customer loyalty research. In particular, passengers' demographic-psychological variables are incorporated into antecedent condition analysis. This option extends the focus on service provider in the relevant literature and reveals the impact of customers' personal characteristics. Although prior research (e.g. Mittal and Kamakura, 2001) has discussed the influence of customer characteristics on repurchase behaviours, this study integrates these characteristics into service provider attributes to analyse their relationships with relationship quality and customer loyalty. Especially use of the asymmetrical testing including contrarian cases provides deeper and more insightful and information for both researchers and practitioners. The study answers the call for a paradigm shift and testing complexity theory in business research (see Woodside, 2013). The asymmetrical testing generates nuanced findings in customer loyalty research that prior research using conventional structural equation modelling or multiple regression techniques has neglected. The gap is bridged in this study by including contrarian cases in the analysis and by looking into asymmetrical relationships between antecedents and outcomes. The contribution also lies in examining the usefulness of modelling causal recipes for predicting outcome variables with appropriate tools for analysis.

The findings of this study have particular implications for practitioners. By employing QCA, airline managers can identify whether and under what circumstances individual attributes and other variables will increase (or decrease) the relationship quality and loyalty. The study helps managers uncover alternative ways for combining the attributes in order to induce loyal behaviours. Identified causal recipes can be used as a guiding tool of allocating appropriate resources for achieving optimal outcomes. In addition to managing and adjusting 
organizational resources, the management and marketers should seek means to understand customers' demographic background and psychological status. For instance, as the study shows that, some passengers who are rated high in mindfulness would stay loyal to their chosen airlines regardless of the airlines' service standard. Directing focus on customer profiling may be a more cost effective way to achieve customer patronage. Despite the emphasis of customer satisfaction in various industries and existing literature, this study reveals that customer satisfaction has a minimal influence on customer behavioural loyalty in the case of air passengers. However, trust in the airline industry plays a significant role in customer attitudes and behaviours. These findings can be a useful guidance and reference for airlines to focus on the causal conditions of trust without excessively undermining the recipes of predicting customer satisfaction. In some cases, satisfied customers express intentions to fly again with their chosen airlines.

\section{Limitations and future research}

Despite deliberate effort in assuring rigorousness in this study, some limitations should be addressed. First, the data were collected in one airport in Europe and the majority of respondents were Europeans, generalisation of the findings may be limited and applied with caution. Multiple regression was only used to compare the findings with those from performing fsQCA. Employing structural equation modelling may provide more insights. The attempt made by the researchers was failed because the sample size was unable to accommodate such large cohort of variables involved in this study. Since the focus of this study is asymmetrical testing, regression analysis is deemed to be adequate to communicate the intended purpose. Finally, the thresholds and criteria for data calibration in fcQCA are rather subjective albeit based on the best knowledge of the researchers. Researchers should be minded of some minor insignificant differences in any future replication attempt. 


\section{REFERENCES}

Akamavi, R. K., Mohamed, E., Pellmann, K, and Xu, Y. (2015). Key determinants of passenger loyalty in the low-cost airline business. Tourism Management, 46, 528-545.

An, M., and Noh, Y. (2009). Airline customer satisfaction and loyalty: impact of in-flight service quality. Service Business, 3(3), 293-307

Athanasopoulou, P. (2009). Relationship quality: a critical literature review and research agenda, European Journal of Marketing, 43(5/6), 583 - 610.

Barber, N. A., and Deale, C. (2014). Tapping mindfulness to shape hotel guests' sustainable behavior. Cornell Hospitality Quarterly, 55(1), 100-114.

Bettencourt, L. A., and Gwinner, K. (1996). Customization of the service experience: the role of the frontline employee. International Journal of Service Industry Management, 7(2), 3-20.

Bishop Gagliano, K., and Hathcote, J. (1994). Customer expectations and perceptions of service quality in retail apparel specialty stores. Journal of Services Marketing, 8(1), 60-69.

Bitner, M. J. (1992). Servicescapes: the impact of physical surroundings on customers and employees. Journal of Marketing, 56, 57-71.

Bowen, J. T., and Shoemaker, S. (1998). Loyalty: A strategic commitment. Cornell hotel and restaurant administration quarterly, 39(1), 12-25.

Caruana, A. (2002). Service loyalty: The effects of service quality and the mediating role of customer satisfaction. European journal of marketing, 36(7/8), 811-828.

Chen, C. F. (2006). Job satisfaction, organizational commitment, and flight attendants' turnover intentions: A note. Journal of Air Transport Management, 12(5), 274-276.

Cooil, B., Keiningham, T. L., Aksoy, L., and Hsu, M. (2007). A longitudinal analysis of customer satisfaction and share of wallet: Investigating the moderating effect of customer characteristics. Journal of marketing, 71(1), 67-83. 
Crosby, L. A., Evans, K. R., and Cowles, D. (1990). Relationship quality in services selling: an interpersonal influence perspective. Journal of Marketing, 54(3), 68-81.

D'Astous, A. (2000). Irritating aspects of the shopping environment. Journal of Business Research, 49, 149-156.

De Wulf, K. D., Odekerken-Schroder, G., and Lacobucci, D. (2001). Investments in Consumer Relationships: A Cross-Country and Cross-Industry Exploration. Journal of Marketing, 65(4), 33-50.

Fiss, P. C. (2007). A Set-theoretic Approach to Organizational Configurations. Academy of Management Review, 32(4), 1180-1198.

Fiss, P. C. (2011). Building Better Causal Theories: A Fuzzy Set Approach to Typologies in Organization Research. Academy of Management Journal, 54(2), 393-420.

Frauman, E., and Norman, W. C. (2004). Mindfulness as a Tool for Managing Visitors to Tourism Destinations, Journal of Travel Research, 42(4), 381-389.

Garbarino, E., and Johnson, M. S. (1999). The different roles of satisfaction, trust, and commitment in customer relationships. Journal of Marketing, 63(2), 70-87.

Greckhamer, T., Misangyi, V. F., Elms, H., and Lacey, R. (2008). Using QCA in Strategic Management Research: An Examination of Combinations of Industry, Corporate, and Business Unit Effects. Organizational Research Methods, 11(4), 695-726.

Griffin, J., and Herres, R. T. (2002). Customer loyalty: How to earn it, how to keep it. San Francisco, CA: Jossey-Bass.

Hair, J. F., Black, W. C., Babin, B. J., and Anderson, R. E. (2010). Multivariate Data Analysis (Global Ed.). Englewood Cliffs, NJ: Prentice Hall.

Hallowell, R. (1996). The relationships of customer satisfaction, customer loyalty, and profitability: an empirical study. International journal of service industry management, 7(4), 27-42. 
Hallowell, R. (1996). The relationships of customer satisfaction, customer loyalty, and profitability: an empirical study. International journal of service industry management, 7(4), 27-42.

Han, H. (2013). Effects of in-flight ambience and space/function on air travelers' decision to select a low-cost airline. Tourism Management, 37, 125-135.

Han, H., and Hwang, J. (2014). In-flight physical surroundings: quality, satisfaction, and traveller loyalty in the emerging low-cost flight market. Current Issues in Tourism. doi: $10.1080 / 13683500.2014 .960371$

Han, H., and Ryu, K. (2009). The roles of the physical environment, price perception, and customer satisfaction in determining customer loyalty in the family restaurant industry. Journal of Hospitality and Tourism Research, 33(4), 487-510.

Hightower, R., Brady, M., and Baker, T. (2002). Investigating the role of the physical environment in hedonic service consumption: An exploratory study of sporting events. Journal of Retailing, 55(9), 697-707. doi:10.1016/S0148-2963(00)00211-3

Jaakkola, E., and Alexander, M. (2014). The role of customer engagement behavior in value cocreation a service system perspective. Journal of Service Research, 17(3), 247-261

Kale, S. H., and Klugsberger, P. (2007). Reaping rewards. Marketing Management, 16(4), 14.

Keaveney, S. M., and Parthasarathy, M. (2001). Customer switching behavior in online services: An exploratory study of the role of selected attitudinal, behavioral, and demographic factors. Journal of the academy of marketing science, 29(4), 374-390.

Kim, W., and Moon, Y. (2009). Customers' cognitive, emotional, and actionable response to the servicescape: a test of the moderating effect of the restaurant type. International Journal of Hospitality Management, 28, 144-156.

Levitt, T. (1986). Relationship Management. In T. Levitt (Ed.), The Marketing Imagination (pp. 111-126). New York, NY: Free. Press. 
Longest, K., and Vaisey, S. (2008). Fuzzy: A Program for Performing Qualitative Comparative Analyses (QCA) in STATA. The STATA Journal, 8(1), 79-104.

Loureiro, S. M. C., and Miranda, F. J. (2008). The importance of quality, satisfaction, trust, and image in relation to rural tourist loyalty. Journal of Travel and Tourism Marketing, 25(2), 117-136.

Loureiro, S.M.C. (2015). Medical tourists' emotional and cognitive response to credibility and Servicescape. Current Issues in Tourism. doi: 10.1080/13683500.2015.1050363

Loureiro, S.M.C., Almeida, M., and Rita, P. (2013). The effect of atmospheric cues and involvement on pleasure and relaxation: The spa hotel context. International Journal of Hospitality management, 35(4), 35-43.

Lovelock, C., and Gummesson, E. (2004). Whither services marketing? In search of a new paradigm and fresh perspectives. Journal of service research, 7(1), 20-41.

Maxham, J. G., and Netemeyer, R. G. (2002). Modeling customer perceptions of complaint handling over time: the effects of perceived justice on satisfaction and intent. Journal of Retailing, 78, 239-252.

Mittal, V., and Kamakura, W. A. (2001). Satisfaction, repurchase intent, and repurchase behavior: Investigating the moderating effect of customer characteristics. Journal of marketing research, 38(1), 131-142.

Moscardo, G. (2009). Understanding tourist experience through Mindfulness Theory. In M. Kozak and A. Decrop (Eds.), Handbook of Tourist Behaviour: Theory and Practice (pp. 99-115). New York: Routledge.

Oliver, R.L. and Swan, J.E. (1989). Consumer Perceptions of Interpersonal Equity and Satisfaction in Transactions: A Field Survey Approach. Journal of Marketing, 53, 21-35. 
Orel, F. D., and Kara, A. (2014). Supermarket self-checkout service quality, customer satisfaction, and loyalty: Empirical evidence from an emerging market. Journal of Retailing and Consumer Services, 21(2), 118-129.

Prentice, C (2013). Service quality perceptions and customer loyalty in casinos. International Journal of Contemporary Hospitality Management. 25(3)49-64.

Prentice, C., \& Woodside, A. G. (2013). Problem gamblers' harsh gaze on casino services. Psychology \& Marketing, 30(12), 1108-1123.

Prentice, C. (2014). Who stays, who walks, and why in high-intensity service contexts. Journal of Business Research. 67(4). 608-614

Rafnsson, V., Tulinius, H., Jónasson, J. G., and Hrafnkelsson, J. (2001). Risk of breast cancer in female flight attendants: a population-based study (Iceland). Cancer Causes and Control, 12(2), 95-101.

Ragin, C. C. (2000). Fuzzy-set Social Science. Chicago, IL: University of Chicago Press.

Ragin, C. C. (2008). Redesigning social inquiry: Fuzzy sets and beyond. University of Chicago Press: Chicago and London.

Rauyruen, P., \& Miller, K. E. (2007). Relationship quality as a predictor of B2B customer loyalty. Journal of business research, 60(1), 21-31.

Rauyruen, P., and Miller, K. E. (2007). Relationship quality as a predictor of B2B customer loyalty. Journal of business research, 60(1), 21-31.

Reichheld, F. F., Markey Jr, R. G., and Hopton, C. (2000). The loyalty effect-the relationship between loyalty and profits. European Business Journal,12(3), 134.

Reynolds, P., Cone, J., Layefsky, M., Goldberg, D. E., and Hurley, S. (2002). Cancer incidence in California flight attendants (United States). Cancer Causes and Control, 13(4), 317-324. 
Ryu, K., and Jang, S. (2007). The effect of environmental perceptions on behavioral intentions through emotions: the case of upscale restaurants. Journal of Hospitality and Tourism Research, 31(1), 56-72.

Sashi, C. M. (2012). Customer engagement, buyer-seller relationships, and social media. Management decision, 50(2), 253-272.

Singh, J. (2000). Performance productivity and quality of frontline employees in service organizations. Journal of marketing, 64(2), 15-34.

Sirdeshmukh, D., Singh, J., \& Sabol, B. (2002). Consumer trust, value, and loyalty in relational exchanges. Journal of marketing, 66(1), 15-37.

Sirdeshmukh, D., Singh, J., \& Sabol, B. (2002). Consumer trust, value, and loyalty in relational exchanges. Journal of marketing, 66(1), 15-37.

Sirianni, N. J., Bitner, M. J., Brown, S. W., and Mandel, N. (2013). Branded service encounters: Strategically aligning employee behavior with the brand positioning. Journal of Marketing, 77(6), 108-123.

Storbacka, K., Strandvik, T., \& Grönroos, C. (1994). Managing customer relationships for profit: the dynamics of relationship quality. International journal of service industry management, 5(5), 21-38.

Storbacka, K., Strandvik, T., and Grönroos, C. (1994). Managing customer relationships for profit: the dynamics of relationship quality. International journal of service industry management, 5(5), 21-38.

Tombs, A., and McColl-Kennedy, J. R. (2003). Social-servicescape conceptual model. Marketing Theory, 3(4), 447-475.

Tsaur, S-H., Wu, D-H., Yen, C-H., and Wu, M-H. (2014). Promoting Relationship Marketing of Tour Leaders' Blog: The Role of Charisma. International Journal of Tourism Research, $16,417-428$. 
Wakefield, K. L., and Blodgett, J. G. (1994). The importance of servicescapes in leisure service settings. Journal of Services Marketing, 8(3), 66-76.

Woodside, A, Prentice, C. Larsen, A.J. (2015). Revisiting Problem Gamblers' Harsh Gaze on Casino Services: Applying Complexity Theory to Identify Exceptional Customers. Psychology and Marketing. 32(1), 65-77

Woodside, A. G. (2013). Moving beyond multiple regression analysis to algorithms: Calling for adoption of a paradigm shift from symmetric to asymmetric thinking in data analysis and crafting theory. Journal of Business Research, 66(4), 463-472.

Zeithaml, V. A., Berry, L. L., and Parasuraman, A. (1996). The behavioral consequences of service quality. Journal of Marketing, 31-46.

Zins, A. H. (2001). Relative attitudes and commitment in customer loyalty models: Some experiences in the commercial airline industry. International Journal of Service Industry Management, 12(3), 269-294.

Zomerdijk, L. G., Voss, C. (2009). Service design for experience-centric services. Journal of service Research, 13(1), 67-82. 


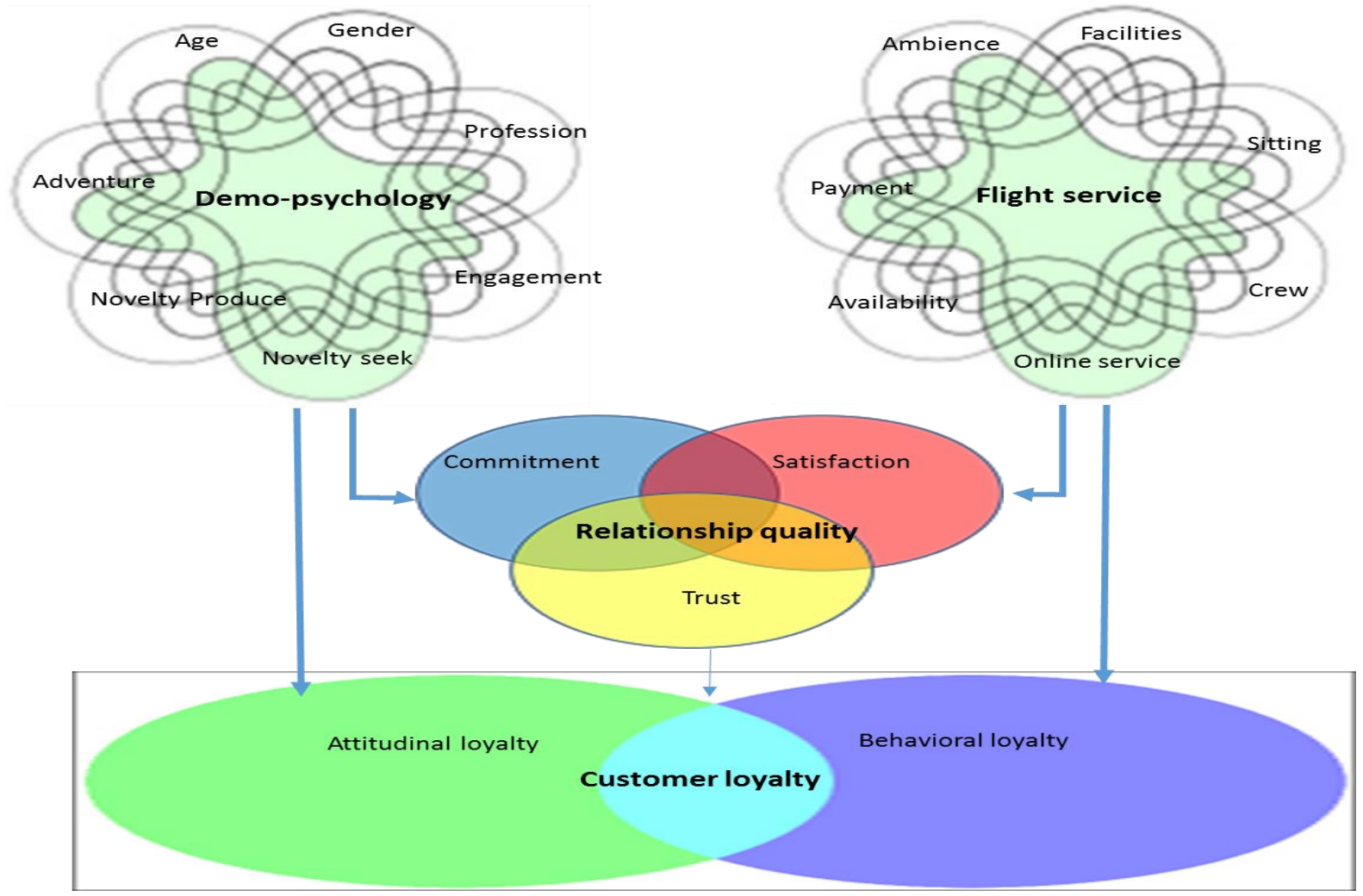

Figure 1. The conceptual model of this study 
Table 1: Correlations among the study variables.

\begin{tabular}{|c|c|c|c|c|c|c|c|c|c|c|c|c|c|c|c|}
\hline Variable & ENG & NP & NS & $\mathrm{AD}$ & AMB & $\overline{\text { FAC }}$ & SIT & CREW & $\mathrm{OL}$ & AVA & PAY & COMT & SAT & TRU & BI $\quad$ BL \\
\hline ENG & .85 & & & & & & & & & & & & & & \\
\hline NP & $.55^{* *}$ & .86 & & & & & & & & & & & & & \\
\hline NS & $.29 * *$ & -.04 & .79 & & & & & & & & & & & & \\
\hline $\mathrm{AD}$ & $.60^{* *}$ & $.48^{* *}$ & $.19^{* *}$ & .77 & & & & & & & & & & & \\
\hline AMB & $.47 * *$ & $.33^{* *}$ & -.04 & $.32^{* *}$ & .91 & & & & & & & & & & \\
\hline FAC & -.04 & $.14^{*}$ & $-.35^{* *}$ & .09 & $.33^{* *}$ & .78 & & & & & & & & & \\
\hline SIT & $.32 * *$ & $.46^{* *}$ & -.09 & $.26^{* *}$ & $.64^{* *}$ & $.39^{* *}$ & .75 & & & & & & & & \\
\hline CREW & $.42^{* *}$ & $.27^{* *}$ & $-.15^{* *}$ & $.37^{* *}$ & $.76^{* *}$ & $.36^{* *}$ & $.60^{* *}$ & .78 & & & & & & & \\
\hline $\mathrm{OL}$ & $.28^{* *}$ & $.22^{* *}$ & -.08 & $.27^{* *}$ & $.25^{* *}$ & -.03 & .05 & $.29^{* *}$ & .77 & & & & & & \\
\hline AVA & .01 & .06 & $-.20^{* *}$ & .04 & $.32^{* *}$ & $.44^{* *}$ & $.41^{* *}$ & $.29^{* *}$ & -.01 & .78 & & & & & \\
\hline PAY & .06 & -.07 & .00 & .03 & .04 & $-.39^{* *}$ & $-.20^{* *}$ & .09 & $.26^{* *}$ & $-.14^{*}$ & .82 & & & & \\
\hline COMT & .07 & -.00 & $-.11^{*}$ & $.17^{* *}$ & $.53^{* *}$ & $.25^{* *}$ & $.42^{* *}$ & $.52^{* *}$ & $.27^{* *}$ & $.41^{* *}$ & .11 & .90 & & & \\
\hline SAT & $.33^{* *}$ & $.13^{*}$ & .06 & $.23^{* *}$ & $.65^{* *}$ & $.22^{* *}$ & $.53^{* *}$ & $.61^{* *}$ & $.23^{* *}$ & $.54^{* * *}$ & $.11^{*}$ & $.70^{* *}$ & .84 & & \\
\hline TRU & $.38^{* *}$ & $.24^{* *}$ & -.08 & $.31^{* *}$ & $.65^{* *}$ & $.37^{* *}$ & $.56^{* *}$ & $.56^{* *}$ & $.18^{* *}$ & $.56^{* *}$ & .03 & $.66^{* *}$ & $.76^{* *}$ & .80 & \\
\hline BI & $.36^{* *}$ & -.06 & -.05 & $.37^{* *}$ & $.52^{* *}$ & .03 & $.20^{* *}$ & $.50^{* *}$ & $.48^{* *}$ & $.30^{* * *}$ & $.35^{* *}$ & $.60^{* *}$ & $.67^{* *}$ & $.55^{* *}$ & .83 \\
\hline $\mathrm{BL}$ & $.29^{* *}$ & .06 & -.02 & $.33^{* *}$ & $.64^{* *}$ & $.29^{* *}$ & $.42^{* *}$ & $.59^{* *}$ & $.30^{* *}$ & $.46^{* *}$ & $.16^{* *}$ & $.67^{* *}$ & $.59^{* *}$ & $.58^{* *}$ & $.53 * * \quad .85$ \\
\hline
\end{tabular}

**. Correlation is significant at the 0.01 level (2-tailed).

*. Correlation is significant at the 0.05 level (2-tailed).

Note: The values in bold are reliabilities for each scale.

$\mathrm{ENG}=$ =ngagement, $\mathrm{NP}=$ novelty producing, $\mathrm{NS}=$ =novelty seeking, $\mathrm{AD}=$ adventuring, $\mathrm{AMB}=$ ambience,

$\mathrm{FAC}=$ facitlities, $\mathrm{SIT}=$ sitting, $\mathrm{CREW}=$ flight attendents, $\mathrm{OL}=$ online services, $\mathrm{AVA}=$ flight availability,

$\mathrm{PAY}=$ payment, $\mathrm{COMT}=$ commitment, $\mathrm{SAT}=$ customer satisfaction, $\mathrm{TRU}=$ trust, $\mathrm{BI}=$ behavioural intention,

$\mathrm{BL}=$ behavioural loyalty. 
Table 2. Calibration of all conditions

\begin{tabular}{lcccccc}
\hline & \multicolumn{2}{c}{ Descriptive statistics } & \multicolumn{3}{c}{ Calibration } \\
\cline { 2 - 7 } Age & Min & Median & Max & 0.95 & 0.50 & 0.05 \\
Gender & 1.00 & 3.00 & 5.00 & 5.00 & 3.00 & 1.00 \\
Profession & Female=0 & Transg=0.5 & Male=1 & 1.00 & 0.50 & 0.00 \\
Ambience & 0.00 & 2.50 & 4.00 & 4.00 & 2.00 & 0.00 \\
Facilities & 2.92 & 3.67 & 4.58 & 4.00 & 3.00 & 2.00 \\
Sitting & 2.00 & 2.75 & 4.00 & 4.00 & 3.00 & 2.00 \\
Crew & 2.33 & 3.33 & 4.33 & 4.00 & 3.00 & 2.00 \\
Online & 3.00 & 4.00 & 4.75 & 4.50 & 3.50 & 2.50 \\
Availability & 3.00 & 4.50 & 5.00 & 5.00 & 3.00 & 1.00 \\
Payment & 2.33 & 3.67 & 4.33 & 4.00 & 3.00 & 2.00 \\
Engagement & 1.00 & 2.80 & 4.60 & 4.50 & 3.50 & 2.50 \\
NoveltyS & 3.33 & 4.00 & 4.83 & 4.50 & 3.50 & 2.50 \\
NoveltyP & 2.71 & 3.71 & 4.14 & 4.00 & 3.00 & 2.00 \\
Adventure & 2.60 & 3.60 & 4.40 & 4.00 & 3.00 & 2.00 \\
Commitment & 3.00 & 4.00 & 5.00 & 5.00 & 4.00 & 3.00 \\
Trust & 1.90 & 3.20 & 4.40 & 4.00 & 3.00 & 2.00 \\
Satisfaction & 2.33 & 3.33 & 4.67 & 4.50 & 3.50 & 2.50 \\
BL & 2.50 & 3.67 & 4.67 & 4.50 & 3.50 & 2.50 \\
AL & 2.30 & 3.60 & 4.60 & 4.50 & 3.50 & 2.50 \\
\hline & 2.75 & 3.75 & 5.00 & 4.00 & 3.00 & 1.00 \\
\hline
\end{tabular}

Note: NoveltyS = novelty seeking, NoveltyP = novelty producing, $\mathrm{BL}=$ behavioural loyalty, $\mathrm{AL}=$ attitudinal loyalty 
Table 3. T-test results between low cost and flag airlines.

\begin{tabular}{llccc}
\hline & Airline & Mean & $\begin{array}{c}\text { Std. } \\
\text { Deviation }\end{array}$ & Sig. \\
\hline Ambience & Low-cost & 3.75 & 0.62 & 0.93 \\
& Flag & 3.68 & 0.62 & \\
Facilities & Low-cost & 2.63 & 0.86 & 0.93 \\
Sitting & Flag & 3.02 & 0.82 & \\
& Low-cost & 3.24 & 0.88 & 0.21 \\
Crew & Flag & 3.36 & 0.79 & \\
& Low-cost & 3.91 & 0.71 & 0.10 \\
Online & Flag & 3.84 & 0.63 & \\
& Low-cost & 4.47 & 0.85 & 0.18 \\
Availability & Flag & 4.17 & 0.93 & \\
& Low-cost & 3.40 & 0.86 & 0.53 \\
Payment & Flag & 3.43 & 0.79 & \\
& Low-cost & 3.24 & 1.13 & 0.77 \\
Satisfaction & Flag & 2.20 & 1.08 & \\
\multirow{2}{*}{ BL } & Low-cost & 3.84 & 0.79 & 0.75 \\
\multirow{2}{*}{ AL } & Flag & 3.63 & 0.80 & \\
& Low-cost & 3.72 & 0.85 & 0.90 \\
& Flag & 3.45 & 0.86 & \\
& Low-cost & 4.05 & 0.81 & 0.15 \\
& Flag & 3.65 & 0.73 & \\
\hline
\end{tabular}

Note: Sample size for low cost $=126$, Flag $=178$ 
Table 4. Regression results for flight attributes predicting outcome variables

\begin{tabular}{|c|c|c|c|c|c|}
\hline Attributes & Satisfaction & Commitment & Trust & $\begin{array}{c}\text { Behavioural } \\
\text { loyalty }\end{array}$ & $\begin{array}{c}\text { Attitudinal } \\
\text { loyalty }\end{array}$ \\
\hline Ambience & $.34 * * *$ & $.24 *$ & $.29 * * *$ & $.31 * * *$ & $.25 * *$ \\
\hline Facilities & $.15^{* *}$ & 0.01 & 0.02 & 0.07 & 0.11 \\
\hline Sitting & 0.1 & $.21 *$ & $.22 * * *$ & 0.01 & $.28 * * *$ \\
\hline Crew & $.19 *$ & 0.02 & 0.09 & $.21 *$ & $.29 * * *$ \\
\hline Online & 0.05 & $.13^{*}$ & 0.03 & $.19 * * *$ & $.19 * * *$ \\
\hline Availability & $.42 * * *$ & $.28 * * *$ & $.33 * * *$ & $.18 * * *$ & $.39 * * *$ \\
\hline Payment & $.09 *$ & 0.08 & 0.05 & $.10^{*}$ & 0.06 \\
\hline Satisfaction & & & & $.35 * * *$ & 0.04 \\
\hline Commitment & & & & $.49 * * *$ & $.59 * * *$ \\
\hline Trust & & & & $.17 * *$ & 0.13 \\
\hline
\end{tabular}

Note: $* \mathbf{p}<.05, * * \mathbf{P}<.001, * * * \mathbf{p}<.0005$ 


\section{Appendices: Truth tables for hypotheses testing}

\section{Table A1. Antecedent conditions of customer satisfaction}

\begin{tabular}{|c|c|c|c|c|c|c|c|c|c|c|c|}
\hline \multirow[b]{3}{*}{ Model } & \multicolumn{7}{|c|}{ Antecedent conditions of customer satisfaction } & \multirow[b]{3}{*}{ Airline } & & & \multirow[b]{3}{*}{ Consistency } \\
\hline & & & & & & & & & \multicolumn{2}{|c|}{ Coverage } & \\
\hline & Pay & Available & Online & Crew & Sitting & Facilities & Ambience & & Raw & Unique & \\
\hline 1 & $\mathrm{X}$ & $\mathrm{O}$ & $\mathrm{X}$ & $\mathrm{O}$ & $\mathrm{O}$ & $\mathrm{O}$ & $\mathrm{O}$ & & 0.42 & 0.14 & 0.95 \\
\hline 2 & $\mathrm{X}$ & $\mathrm{O}$ & $X$ & & $\mathrm{O}$ & $\mathrm{O}$ & $\mathrm{O}$ & & 0.25 & 0.02 & 0.98 \\
\hline 3 & $\mathrm{O}$ & $\mathrm{O}$ & & $\mathrm{O}$ & $\mathrm{O}$ & $\mathrm{O}$ & $\mathrm{O}$ & $X$ & 0.14 & 0.03 & 0.97 \\
\hline 4 & $\mathrm{O}$ & $X$ & $X$ & $X$ & $X$ & $X$ & $\mathrm{O}$ & & 0.17 & 0.01 & 0.99 \\
\hline 5 & $\mathrm{O}$ & $X$ & $X$ & $X$ & $X$ & $\mathrm{O}$ & $\mathrm{O}$ & & 0.14 & 0.01 & 0.97 \\
\hline 6 & $\mathrm{O}$ & $X$ & & $X$ & $X$ & $X$ & $\mathrm{O}$ & $\mathrm{O}$ & 0.1 & 0.02 & 0.96 \\
\hline 7 & $X$ & $\mathrm{O}$ & $\mathrm{O}$ & $X$ & $X$ & $\mathrm{O}$ & $X$ & $X$ & 0.05 & 0.01 & 0.95 \\
\hline 8 & $\mathrm{O}$ & $\mathrm{O}$ & $X$ & $X$ & $X$ & $\mathrm{O}$ & $X$ & $\mathrm{O}$ & 0.09 & 0.01 & 0.96 \\
\hline
\end{tabular}

Solution coverage: 0.56 , Solution consistency: 0.95 , Consistency cut-off: 0.95

Table A2. Antecedent conditions of customer satisfaction

\begin{tabular}{|c|c|c|c|c|c|c|c|c|c|c|c|}
\hline \multirow[b]{3}{*}{ Model } & \multicolumn{7}{|c|}{ Antecedent conditions of customer satisfaction } & \multirow[b]{3}{*}{ Airline } & & & \multirow[b]{3}{*}{ Consistency } \\
\hline & & & & & & & & & \multicolumn{2}{|c|}{ Coverage } & \\
\hline & Advent & Noveltys & Noveltyp & Engage & Prof & Age & Gender & & Raw & Unique & \\
\hline 1 & $\mathrm{X}$ & $\mathrm{O}$ & $\mathrm{X}$ & $\mathrm{O}$ & $\mathrm{X}$ & $\mathrm{X}$ & $\mathrm{M}$ & & 0.07 & 0.01 & 0.97 \\
\hline 2 & $\mathrm{X}$ & $\mathrm{X}$ & $\mathrm{X}$ & $\mathrm{O}$ & $X$ & $X$ & $\mathrm{M} / \mathrm{F}$ & $\mathrm{O}$ & 0.08 & 0.03 & 0.96 \\
\hline 3 & $\mathrm{X}$ & $\mathrm{X}$ & $\mathrm{X}$ & $\mathrm{O}$ & $\mathrm{O}$ & $\mathrm{O}$ & M & & 0.08 & 0.03 & 0.96 \\
\hline 4 & 0 & $X$ & 0 & $\mathrm{O}$ & 0 & 0 & $\mathrm{M} / \mathrm{F}$ & $X$ & 0.06 & 0.03 & 0.96 \\
\hline 5 & $X$ & & $X$ & $\mathrm{O}$ & $\mathrm{O}$ & 0 & $\mathrm{M} / \mathrm{F}$ & 0 & 0.06 & 0.01 & 0.96 \\
\hline 6 & $\mathrm{O}$ & $\mathrm{O}$ & $\mathrm{O}$ & $\mathrm{O}$ & $X$ & $X$ & $\mathrm{~F}$ & $X$ & 0.04 & 0.03 & 0.95 \\
\hline
\end{tabular}

Solution coverage: 0.22 , Solution consistency: 0.96, Consistency cut-off: 0.95 
Table A3. Antecedent conditions for customer commitment

\begin{tabular}{|c|c|c|c|c|c|c|c|c|c|c|c|}
\hline \multirow[b]{3}{*}{ Model } & \multicolumn{7}{|c|}{ Antecedent conditions of Commitment } & & & & \multirow[b]{3}{*}{ Consistency } \\
\hline & & & & & & & & & \multicolumn{2}{|c|}{ Coverage } & \\
\hline & Advent & Noveltys & Noveltyp & Engage & Prof & Age & Gender & Airline & Raw & Unique & \\
\hline 1 & $\mathrm{O}$ & $\mathrm{X}$ & $\mathrm{O}$ & $\mathrm{O}$ & $\mathrm{O}$ & $\mathrm{O}$ & $\mathrm{M} / \mathrm{F}$ & & 0.26 & 0.07 & 0.84 \\
\hline 2 & $\mathrm{O}$ & $X$ & $\mathrm{O}$ & $\mathrm{O}$ & $X$ & $\mathrm{X}$ & M & $\mathrm{O}$ & 0.06 & 0.03 & 0.81 \\
\hline & & & & & & & & & & & \\
\hline
\end{tabular}

Table A4. Antecedent conditions for customer commitment

\begin{tabular}{|c|c|c|c|c|c|c|c|c|c|c|c|}
\hline \multirow[b]{3}{*}{ Model } & \multicolumn{7}{|c|}{ Antecedent conditions of commitment } & & & & \multirow[b]{3}{*}{ Consistency } \\
\hline & & & & & & & & & \multicolumn{2}{|c|}{ Coverage } & \\
\hline & Pay & Available & Online & Crew & Sitting & Facilities & Ambience & Airline & Raw & Unique & \\
\hline 1 & $\mathrm{X}$ & $\mathrm{O}$ & & $\mathrm{O}$ & $\mathrm{O}$ & $\mathrm{O}$ & $\mathrm{O}$ & & 0.42 & 0.07 & 0.91 \\
\hline 2 & & $\mathrm{O}$ & $\mathrm{O}$ & $\mathrm{O}$ & $\mathrm{O}$ & $\mathrm{O}$ & $\mathrm{O}$ & & 0.42 & 0.08 & 0.93 \\
\hline 3 & $\mathrm{X}$ & & $\mathrm{X}$ & $\mathrm{O}$ & $\mathrm{O}$ & $\mathrm{O}$ & $\mathrm{O}$ & $\mathrm{X}$ & 0.08 & 0.01 & 0.84 \\
\hline 4 & $\mathrm{O}$ & $\mathrm{O}$ & $X$ & $\mathrm{O}$ & $\mathrm{O}$ & & $\mathrm{O}$ & $X$ & 0.07 & 0.02 & 0.86 \\
\hline
\end{tabular}

Solution coverage: 0.53 , Solution consistency: 0.89 , Consistency cut-off: 0.94 
Table A5. Findings for antecedent conditions of customer trust

\begin{tabular}{|c|c|c|c|c|c|c|c|c|c|c|c|}
\hline \multirow[b]{3}{*}{ Model } & \multicolumn{7}{|c|}{ Antecedent conditions of customer trust } & \multirow[b]{3}{*}{ Airline } & & & \multirow[b]{3}{*}{ Consistency } \\
\hline & & & & & & & & & \multicolumn{2}{|c|}{ Coverage } & \\
\hline & Advent & Noveltys & Noveltyp & Engage & Prof & Age & Gender & & Raw & Unique & \\
\hline 1 & $\mathrm{O}$ & $\mathrm{O}$ & $\mathrm{O}$ & $\mathrm{O}$ & $\mathrm{X}$ & $\mathrm{X}$ & $\mathrm{F}$ & & 0.11 & 0.05 & 0.94 \\
\hline 2 & $\mathrm{O}$ & $\mathrm{X}$ & $\mathrm{O}$ & $\mathrm{O}$ & $\mathrm{O}$ & $\mathrm{O}$ & $\mathrm{M} / \mathrm{F}$ & $\mathrm{X}$ & 0.06 & 0.03 & 0.97 \\
\hline 3 & $\mathrm{X}$ & $X$ & $\mathrm{O}$ & $\mathrm{O}$ & $\mathrm{X}$ & $\mathrm{X}$ & $\mathrm{F}$ & $\mathrm{X}$ & 0.03 & 0.01 & 0.91 \\
\hline 4 & $X$ & $\mathrm{O}$ & $\mathrm{O}$ & $X$ & $X$ & $X$ & $\mathrm{M}$ & $\mathrm{O}$ & 0.05 & 0.02 & 0.92 \\
\hline 5 & $X$ & $X$ & $\mathrm{O}$ & $\mathrm{O}$ & $\mathrm{O}$ & $\mathrm{O}$ & F & $\mathrm{O}$ & 0.06 & 0.04 & 0.91 \\
\hline 6 & $X$ & $X$ & $X$ & $\mathrm{O}$ & $\mathrm{O}$ & $\mathrm{O}$ & $\mathrm{M}$ & $\mathrm{O}$ & 0.05 & 0.03 & 0.91 \\
\hline 7 & $\mathrm{O}$ & $\mathrm{O}$ & $X$ & $\mathrm{O}$ & $\mathrm{O}$ & $\mathrm{O}$ & $\mathrm{M}$ & $X$ & 0.04 & 0.02 & 0.91 \\
\hline 8 & $\mathrm{O}$ & $\mathrm{O}$ & $\mathrm{O}$ & $\mathrm{O}$ & $\mathrm{X}$ & $\mathrm{O}$ & $\mathrm{M}$ & $\mathrm{O}$ & 0.05 & 0.02 & 0.91 \\
\hline
\end{tabular}

Solution coverage: 0.30 , Solution consistency: 0.92 , Consistency cut-off: 0.95

Table A6. Findings of antecedent conditions of customer trust

\begin{tabular}{|c|c|c|c|c|c|c|c|c|c|c|c|}
\hline \multirow[b]{3}{*}{ Model } & \multicolumn{7}{|c|}{ Antecedent conditions of customer trust } & \multirow[b]{3}{*}{ Airline } & & & \multirow[b]{3}{*}{ Consistency } \\
\hline & & & & & & & & & \multicolumn{2}{|c|}{ Coverage } & \\
\hline & Pay & Available & Online & Crew & Sitting & Facilities & Ambience & & Raw & $\overline{\text { Unique }}$ & \\
\hline 1 & $\mathrm{X}$ & $\mathrm{O}$ & $\mathrm{X}$ & $\mathrm{O}$ & $\mathrm{O}$ & $\mathrm{O}$ & $\mathrm{O}$ & & 0.46 & 0.16 & 0.97 \\
\hline 2 & $\mathrm{X}$ & & $\mathrm{X}$ & $\mathrm{O}$ & $\mathrm{O}$ & $\mathrm{O}$ & $\mathrm{O}$ & & 0.26 & 0.02 & 0.96 \\
\hline 3 & $\mathrm{O}$ & $\mathrm{O}$ & $\mathrm{X}$ & $\mathrm{O}$ & $\mathrm{O}$ & $\mathrm{O}$ & $\mathrm{O}$ & & 0.18 & 0.01 & 0.96 \\
\hline 4 & $\mathrm{X}$ & $X$ & $\mathrm{O}$ & $\mathrm{O}$ & $\mathrm{O}$ & $X$ & $\mathrm{O}$ & $X$ & 0.11 & 0.01 & 0.94 \\
\hline 5 & $\mathrm{O}$ & $X$ & $\mathrm{O}$ & $\mathrm{O}$ & $\mathrm{O}$ & $X$ & $\mathrm{O}$ & & 0.20 & 0.02 & 0.96 \\
\hline 6 & $\mathrm{O}$ & $X$ & $X$ & $X$ & $X$ & $X$ & $\mathrm{O}$ & $X$ & 0.06 & 0.01 & 0.95 \\
\hline 7 & $\mathrm{O}$ & $\mathrm{O}$ & $\mathrm{O}$ & $\mathrm{O}$ & $\mathrm{O}$ & $\mathrm{O}$ & $\mathrm{O}$ & $X$ & 0.15 & 0 & 0.97 \\
\hline 8 & $\mathrm{O}$ & $X$ & $\mathrm{O}$ & $\mathrm{O}$ & $\mathrm{O}$ & $X$ & $\mathrm{O}$ & $X$ & 0.13 & 0 & 0.97 \\
\hline
\end{tabular}


Table A7. Findings for antecedent conditions of behavioural loyalty

\begin{tabular}{|c|c|c|c|c|c|c|c|c|c|c|c|}
\hline \multirow[b]{3}{*}{ Model } & \multicolumn{7}{|c|}{ Antecedent conditions of behavioral loyalty } & \multirow[b]{3}{*}{ Airline } & & & \multirow[b]{3}{*}{ Consistency } \\
\hline & & & & & & & & & \multicolumn{2}{|c|}{ Coverage } & \\
\hline & Advent & Noveltys & Noveltyp & Engage & Prof & Age & Gender & & Raw & Unique & \\
\hline 1 & & $\mathrm{X}$ & $\mathrm{O}$ & $\mathrm{O}$ & $\mathrm{O}$ & $\mathrm{O}$ & $\mathrm{F}$ & $\mathrm{X}$ & 0.41 & 0.01 & 0.93 \\
\hline 2 & $\mathrm{O}$ & $\mathrm{O}$ & $\mathrm{X}$ & $\mathrm{O}$ & $\mathrm{O}$ & $\mathrm{O}$ & $\mathrm{M} / \mathrm{F}$ & $\mathrm{X}$ & 0.08 & 0.02 & 0.97 \\
\hline 3 & $\mathrm{O}$ & $\mathrm{O}$ & $\mathrm{X}$ & $\mathrm{O}$ & $\mathrm{O}$ & $\mathrm{O}$ & $\mathrm{F}$ & & 0.08 & 0.05 & 0.94 \\
\hline 4 & $\mathrm{O}$ & $X$ & $\mathrm{O}$ & $\mathrm{O}$ & $\mathrm{O}$ & $\mathrm{O}$ & $\mathrm{M} / \mathrm{F}$ & $X$ & 0.08 & 0.05 & 0.96 \\
\hline 5 & $\mathrm{O}$ & $\mathrm{O}$ & $X$ & $X$ & $X$ & $X$ & $\mathrm{~F}$ & $X$ & 0.06 & 0.02 & 0.96 \\
\hline 6 & $\mathrm{O}$ & $\mathrm{O}$ & $X$ & $X$ & $X$ & $X$ & M & $X$ & 0.03 & 0.01 & 0.94 \\
\hline 7 & $X$ & $\mathrm{O}$ & $X$ & $\mathrm{O}$ & $X$ & $X$ & $\mathrm{M}$ & $X$ & 0.03 & 0.01 & 0.93 \\
\hline
\end{tabular}

Solution coverage: 0.19 , Solution consistency: 0.93, Consistency cut-off: 0.93

Table A8. Findings for antecedent conditions of customer behavioural loyalty

\begin{tabular}{|c|c|c|c|c|c|c|c|c|c|c|c|}
\hline \multirow[b]{3}{*}{ Model } & \multicolumn{7}{|c|}{ Antecedent conditions of customer behavioral loyalty } & \multirow[b]{3}{*}{ Airline } & & & \multirow[b]{3}{*}{ Consistency } \\
\hline & & & & & & & & & \multicolumn{2}{|c|}{ Coverage } & \\
\hline & Pay & Available & Online & Crew & Sitting & Facilities & Ambience & & Raw & Unique & \\
\hline 1 & $\mathrm{O}$ & $\mathrm{O}$ & $\mathrm{X}$ & $\mathrm{O}$ & $\mathrm{O}$ & $\mathrm{O}$ & $\mathrm{O}$ & $\mathrm{X}$ & 0.15 & 0.03 & 0.96 \\
\hline 2 & $\mathrm{X}$ & $\mathrm{O}$ & $\mathrm{O}$ & $\mathrm{O}$ & $\mathrm{O}$ & $\mathrm{O}$ & $\mathrm{O}$ & $\mathrm{X}$ & 0.15 & 0.01 & 0.96 \\
\hline 3 & $\mathrm{O}$ & $X$ & $\mathrm{O}$ & $\mathrm{O}$ & $\mathrm{O}$ & $\mathrm{O}$ & $\mathrm{O}$ & & 0.37 & 0.16 & 0.98 \\
\hline 4 & $\mathrm{O}$ & $\mathrm{O}$ & $X$ & $\mathrm{O}$ & $\mathrm{O}$ & $X$ & $\mathrm{O}$ & & 0.16 & 0.03 & 0.95 \\
\hline 5 & $\mathrm{O}$ & $X$ & $\mathrm{O}$ & $\mathrm{O}$ & $X$ & $\mathrm{O}$ & $\mathrm{O}$ & & 0.16 & 0.04 & 0.93 \\
\hline 6 & $X$ & $\mathrm{O}$ & $\mathrm{O}$ & $X$ & $X$ & $\mathrm{O}$ & $X$ & $X$ & 0.05 & 0.01 & 0.93 \\
\hline 7 & $X$ & $X$ & $\mathrm{O}$ & $\mathrm{O}$ & $\mathrm{O}$ & $X$ & $\mathrm{O}$ & $X$ & 0.07 & 0.01 & 0.93 \\
\hline 8 & $\mathrm{O}$ & $\mathrm{O}$ & $\mathrm{O}$ & $X$ & $X$ & $X$ & $X$ & $\mathrm{O}$ & 0.09 & 0.01 & 0.93 \\
\hline 9 & $\mathrm{O}$ & $X$ & $\mathrm{O}$ & $X$ & $X$ & $X$ & $\mathrm{O}$ & $\mathrm{O}$ & 0.09 & 0.01 & 0.94 \\
\hline
\end{tabular}


Table A9. Findings for antecedent conditions of attitudinal loyalty

\begin{tabular}{|c|c|c|c|c|c|c|c|c|c|c|c|}
\hline \multirow[b]{3}{*}{ Model } & \multicolumn{7}{|c|}{ Antecedent conditions of behavioral intentions } & \multirow[b]{3}{*}{ Airline } & & & \multirow[b]{3}{*}{ Consistency } \\
\hline & & & & & & & & & \multicolumn{2}{|c|}{ Coverage } & \\
\hline & Advent & Noveltys & Noveltp & Engage & Prof & Age & Gender & & Raw & Unique & \\
\hline 1 & $\mathrm{X}$ & $X$ & $\mathrm{X}$ & $\mathrm{O}$ & $\mathrm{O}$ & $\mathrm{O}$ & F & $\mathrm{X}$ & 0.04 & 0.01 & 0.96 \\
\hline 2 & $\mathrm{X}$ & $X$ & $\mathrm{X}$ & $\mathrm{O}$ & $\mathrm{O}$ & $\mathrm{O}$ & $\mathrm{M} / \mathrm{F}$ & $\mathrm{X}$ & 0.07 & 0.01 & 0.98 \\
\hline 3 & $\mathrm{X}$ & $\mathrm{O}$ & $X$ & $\mathrm{O}$ & $X$ & $X$ & $\mathrm{M}$ & & 0.08 & 0.01 & 0.97 \\
\hline 4 & $X$ & $\mathrm{O}$ & $X$ & $\mathrm{O}$ & $X$ & $\mathrm{X}$ & $\mathrm{M} / \mathrm{F}$ & $\mathrm{O}$ & 0.08 & 0.02 & 0.94 \\
\hline 5 & $\mathrm{O}$ & $\mathrm{O}$ & $X$ & $\mathrm{O}$ & $\mathrm{O}$ & $\mathrm{O}$ & $\mathrm{M} / \mathrm{F}$ & $X$ & 0.07 & 0.02 & 0.94 \\
\hline 6 & $\mathrm{O}$ & $\mathrm{O}$ & $X$ & $\mathrm{O}$ & $\mathrm{O}$ & $\mathrm{O}$ & $\mathrm{M} / \mathrm{F}$ & & 0.08 & 0.02 & 0.95 \\
\hline 7 & $\mathrm{O}$ & $X$ & $\mathrm{O}$ & $\mathrm{O}$ & $\mathrm{O}$ & $\mathrm{O}$ & $\mathrm{M} / \mathrm{F}$ & $X$ & 0.06 & 0.02 & 0.96 \\
\hline 8 & $X$ & $X$ & $X$ & $\mathrm{O}$ & $\mathrm{O}$ & $\mathrm{O}$ & M & $\mathrm{O}$ & 0.06 & 0.04 & 0.95 \\
\hline 9 & $X$ & $X$ & $X$ & $\mathrm{O}$ & $X$ & $X$ & $\mathrm{~F}$ & $X$ & 0.03 & 0.01 & 0.99 \\
\hline 10 & $\mathrm{O}$ & $\mathrm{O}$ & $X$ & $X$ & $X$ & $X$ & $\mathrm{M}$ & $X$ & 0.03 & 0.01 & 0.98 \\
\hline 11 & $\mathrm{O}$ & $\mathrm{O}$ & $\mathrm{O}$ & $\mathrm{O}$ & $X$ & $X$ & $\mathrm{~F}$ & $X$ & 0.05 & 0.02 & 0.97 \\
\hline
\end{tabular}

Solution coverage: 0.33 , Solution consistency: 0.95 , Consistency cut-off: 0.94

Table A10. Findings for antecedent conditions of attitudinal loyalty

\begin{tabular}{|c|c|c|c|c|c|c|c|c|c|c|c|}
\hline \multirow[b]{3}{*}{ Model } & \multicolumn{7}{|c|}{ Antecedent conditions of customer behavioral intention } & & & & \multirow[b]{3}{*}{ Consistency } \\
\hline & & & & & & & & & \multicolumn{2}{|c|}{ Coverage } & \\
\hline & Pay & Available & Online & Crew & Sitting & Facilities & Ambience & Airline & Raw & Unique & \\
\hline 1 & $\mathrm{O}$ & $\mathrm{X}$ & $\mathrm{X}$ & $\mathrm{X}$ & $\mathrm{X}$ & $\mathrm{X}$ & $\mathrm{O}$ & & 0.21 & 0.03 & 0.93 \\
\hline 2 & & $\mathrm{O}$ & & $\mathrm{O}$ & $\mathrm{O}$ & $\mathrm{O}$ & $\mathrm{O}$ & $\mathrm{X}$ & 0.14 & 0.03 & 0.91 \\
\hline 3 & $\mathrm{O}$ & $\mathrm{O}$ & $\mathrm{O}$ & $X$ & $X$ & $X$ & $\mathrm{X}$ & & 0.18 & 0.04 & 0.96 \\
\hline 4 & $X$ & $\mathrm{O}$ & $\mathrm{O}$ & $X$ & $X$ & $\mathrm{O}$ & $X$ & & 0.2 & 0.08 & 0.98 \\
\hline 5 & & $X$ & $\mathrm{O}$ & $\mathrm{O}$ & $\mathrm{O}$ & $X$ & $\mathrm{O}$ & $X$ & 0.11 & 0.01 & 0.93 \\
\hline 6 & $\mathrm{O}$ & $\mathrm{O}$ & $X$ & $\mathrm{O}$ & $\mathrm{O}$ & $X$ & $\mathrm{O}$ & & 0.16 & 0.01 & 0.95 \\
\hline 7 & $\mathrm{O}$ & $X$ & $\mathrm{O}$ & $\mathrm{O}$ & $X$ & $\mathrm{O}$ & $\mathrm{O}$ & & 0.16 & 0.04 & 0.97 \\
\hline 8 & $\mathrm{O}$ & $\mathrm{O}$ & $\mathrm{O}$ & $\mathrm{O}$ & $\mathrm{O}$ & $\mathrm{O}$ & $\mathrm{O}$ & & 0.21 & 0.04 & 0.95 \\
\hline 9 & $\mathrm{O}$ & $\mathrm{O}$ & $\mathrm{O}$ & $\mathrm{O}$ & $\mathrm{O}$ & $\mathrm{O}$ & $\mathrm{O}$ & $X$ & 0.15 & 0 & 0.95 \\
\hline 10 & $\mathrm{O}$ & $\mathrm{O}$ & $\mathrm{O}$ & $\mathrm{O}$ & $\mathrm{O}$ & $X$ & $\mathrm{O}$ & $X$ & 0.13 & 0 & 0.95 \\
\hline
\end{tabular}


Table A11. Findings for antecedent conditions of behavioural loyalty

\begin{tabular}{|c|c|c|c|c|c|c|c|}
\hline \multirow[b]{3}{*}{ Model } & \multicolumn{4}{|c|}{ Antecedent conditions of customer behavioral loyalty } & & & \multirow[b]{3}{*}{ Consistency } \\
\hline & & & & & \multicolumn{2}{|c|}{ Coverage } & \\
\hline & Trust & Commit & Satisf & Airline & Raw & Unique & \\
\hline 1 & $\mathrm{O}$ & $\mathrm{O}$ & & & 0.70 & 0.61 & 0.94 \\
\hline 2 & $\mathrm{O}$ & $\mathrm{X}$ & & $\mathrm{X}$ & 0.15 & 0.06 & 0.85 \\
\hline & & & & & & & \\
\hline
\end{tabular}

Table A12. Findings for antecedent conditions of attitudinal loyalty

\begin{tabular}{|c|c|c|c|c|c|c|c|}
\hline \multirow[b]{3}{*}{ Model } & \multicolumn{4}{|c|}{ Antecedent conditions of customer behavioral intention } & & & \multirow[b]{3}{*}{ Consistency } \\
\hline & & & & & \multicolumn{2}{|c|}{ Coverage } & \\
\hline & Trust & Commit & Satisf & Airline & Raw & Unique & \\
\hline 1 & $\mathrm{O}$ & & & $\mathrm{X}$ & 0.38 & 0.17 & 0.87 \\
\hline 2 & & $\mathrm{X}$ & $\mathrm{O}$ & $\mathrm{X}$ & 0.24 & 0.05 & 0.89 \\
\hline$\underline{3}$ & $\underline{\mathrm{O}}$ & $\underline{\mathrm{O}}$ & $\underline{X}$ & & $\underline{0.26}$ & $\underline{0.17}$ & $\underline{0.88}$ \\
\hline & & & & & & & \\
\hline
\end{tabular}

